\title{
The Efficacy of Promoting Financial Literacy with MOOC among Economics Pre-Service Teachers
}

\author{
Khoo Yin Yin \\ Sultan Idris Education University \\ https:/ / orcid.org/0000-0003-4850-2184 \\ Derek Watson \\ University Sunderland \\ https:/ / orcid.org/0000-0002-1944-3544 \\ Rohaila Yusof \\ Sultan Idris Education University \\ https://orcid.org/0000-0001-5304-8970
}

\begin{abstract}
It is important to educate financial literacy to pre-service teachers to manage their money well and to disseminate the knowledge to their students. The study aimed to examine the effectiveness of MOOC in promoting financial literacy among pre-service teachers. This paper also examines the correlation among the variables of financial literacy, collaborative skills, problem-solving, accountability, and decisionmaking. Pre-service teachers' views were discussed after attending the MOOC. The study adopted a mixed-method research design. A total of 100 pre-service teachers were selected through a random-sampling technique to participate in the survey. A purposive sampling technique was used to pick five of the participants for the follow-up interview. The quantitative data were analyzed with descriptive and inferential statistics, while the qualitative data were analyzed on the basis of content analysis. The quantitative method yielded favourable descriptive statistics; and they also showed a significant relationship between financial literacy and MOOC. The variables indicated some correlations. The qualitative results also revealed the positive responses of financial literacy, collaborative skills, problem-solving, accountability, and decision-making. The course design and participants' engagement are the key factors of the success of MOOCs. Future research should emphasize the incorporation of financial literacy into different subjects. Educators and researchers could well provide more online learning in addition to those activities that combine financial literacy in other courses.
\end{abstract}

Keywords: financial literacy; Economics pre-service teachers; MOOCs; collaborative skills; accountability; problem-solving 


\section{Introduction}

Massive open online course (MOOC) is a widespread application of informationtechnology education (Haron et al., 2019). Initially introduced in Malaysia in 2015, MOOCs are now considered a new e-learning platform that was later implemented by the Malaysian Higher Education Institutions (Kumar \& AlSamarraie, 2018). By utilizing the platform of MOOCs, it is possible to create a conducive learning forum that allows learning to happen anywhere and in any place (Hassan et al., 2015 Qaffas et al., 2020). It is also recognized that MOOC provides open learning to the enrolled participants; and the students can follow the course at their own place and pace.

Most of the MOOCs in Malaysia offer academic courses; nevertheless, a minority of courses have failed to embrace the essential skills, such as financial literacy. If financial literacy is not prioritized, there could well be negative consequences. For example, a total of $47 \%$ of bankruptcies in Malaysia involved young adults (Nurul Afiqah, 2016; Khoo \& Fitzgerald, 2017). There is a significant tendency for millennials to spend beyond their means; since they are often easily influenced by the social media; and, in consequence, they are inclined to buy expensive and branded goods (Caixeta et al., 2016; Khan et al., 2019). For example, 38.8\% of young people between the ages of 20 and 24 repeatedly upgrade their smartphones to the latest model (Malaysian Communications and Multimedia Commission, 2015).

In contrast, the consequences of the financial crisis have elevated the importance of financial literacy. The Organization of Economic Co-Operation and Development (2014) raised the importance of financial literacy; and it was highly recommended that it should be included within the school curriculum. The OECD further stressed the importance of educating financial literacy to all citizens, in order to instil better financial management of their own funds and to enhance their financial well-being. The Malaysian Government supported this study; and it is evident in other countries, such as the United States and Australia, which have integrated these recommendations (Cordero \& Pedraja, 2019).

Financial literacy has been the only cross-curricular element in Malaysia's curriculum since 2017, resulting in the Financial Education Network being launched in 2019 (Financial Education Network, 2019). Teachers are encouraged to include financial literacy in their classes, in order to enhance their students' awareness of financial literacy (Sawatzki \& Sullivan, 2017). Evidence suggests that teachers no longer regard financial literacy as not being a key priority; since it is not a standalone subject in the Malaysian secondary-schooling system (Mohd Aziz \& Kassim, 2020). This view has influenced students' perception in learning financial literacy. Furthermore, teachers rarely attend developmental courses; and consequently, they struggle to integrate this critical skill into their schemes of work effectively. However, research in this area is rather limited; and this reflects the research gap. In addition, the academic debate of utilizing MOOCs in financial literacy is limited; and in consequence, there is a research gap to be filled. This issue is the research gap that is yet to be filled in this study. Pre-service teachers, who will become qualified teachers, should be exposed to an incorporated financial literacy, which would later be transmitted to the students during class. 
Unfortunately, some teachers claimed that they could not cover financial literacy in class, due to time constraints (Rakow, 2019). The same study also mentioned that many teachers are frequently pressed for time; and they are forced to omit specific topics, such as financial literacy. These barriers could be bridged if teachers were to undertake proper training on the pedagogical application and positive impacts of financial literacy. However, due to the lack of financial literacy for graduates, they must seek advice from financial planning services for personal financial management.

On a more positive note, researchers have indicated that students, who studied financial education developed financial literacy, when compared to those who did not attend the class (Murugiah, 2016; Zhu, 2018; Haneger \& Cude, 2019). The OECD further stated that education could help bridge the financial-literacy gap, and that financial education programmes have been found to successfully improve students' and adolescents' financial knowledge and attitudes (OECD, 2013).

Many researchers only focused on pedagogical skills and on the content knowledge of teacher-training courses; in fact, some essential life skills should also be emphasized among them (Prajapati et al., 2017). Since every pre-service teacher has both generic and bespoke learning styles, the practical learning platform should be tailored, in ordered to meet the learners' needs. The learning platform must have the necessary flexibility to encompass various learning pedagogies, such as live-case studies, presentations, etc. MOOC is a popular learning mode that offers such flexibility; and furthermore, it is an affordable way to learn.

In addition, prior research showed evidence that financial literacy can be effectively taught, together with the help of digital tools (Angel, 2018; Kuntze et al., 2019). Angel (2018) and Kuntze et al. (2019) shared the same views that online learning using different devices, could enhance financial literacy. Therefore, MOOCs, together with words and videos, are the most suitable platform from which to implement financial literacy.

The main contribution of the current study to the practical gap, is to help preservice teachers to acquire important skills, such as collaborative skills, and to incorporate financial literacy into their lessons through practical activities. In addition, this study has also contributed to the literature on Economics education that focuses on community pre-service teachers. Despite the lack of financial literacy among young adults, there has also been a lack of research that could improve financial knowledge and promote financial awareness among preservice teachers. The population of pre-service teachers concerning the effectiveness of financial literacy through digital platforms is the significant result of this study.

\section{Objective}

This paper aimed to answer the following research objectives:

1. To explore the effectiveness of MOOC in promoting financial literacy among pre-service teachers. 
2. To investigate the correlation among financial-literacy variables, collaborative skills, accountability, problem-solving skills and decision-making.

3. To examine pre-service teachers' views on financial literacy after attending the MOOC.

\section{The Literature review}

\subsection{The Conceptual Framework}

This study is based on Mayer's Multimedia Learning Theory. In Mayer's Multimedia Learning Theory, the student engages in five important cognitive processes. Mayer (2014) stated that meaningful learning from words and pictures occurs, when the learner engages in five cognitive processes, which are:

1. Choosing the relevant words for processing in verbal-working memory;

2. Selecting relevant images for processing in visual-working memory;

3. Organizing the selected words into a verbal model;

4. Organizing selected images into a pictorial model; and

5. Integrating the verbal and pictorial representations with prior knowledge.

These cognitive processes determine what information is to be drawn upon in the working memory, when knowledge is retrieved from one's long-term memory and integrated with new information, in order to construct new knowledge. The new knowledge in the working memory will be relocated and transferred to long-term memory through the process of encoding (Mayer, 2014). Refer to Figure 1. MOOCs have met the criteria of Multimedia Learning; since they are colorful, animated pictures and can transform words into pictures. Furthermore, students can cope with the knowledge of financial literacy by utilising their tacit knowledge.

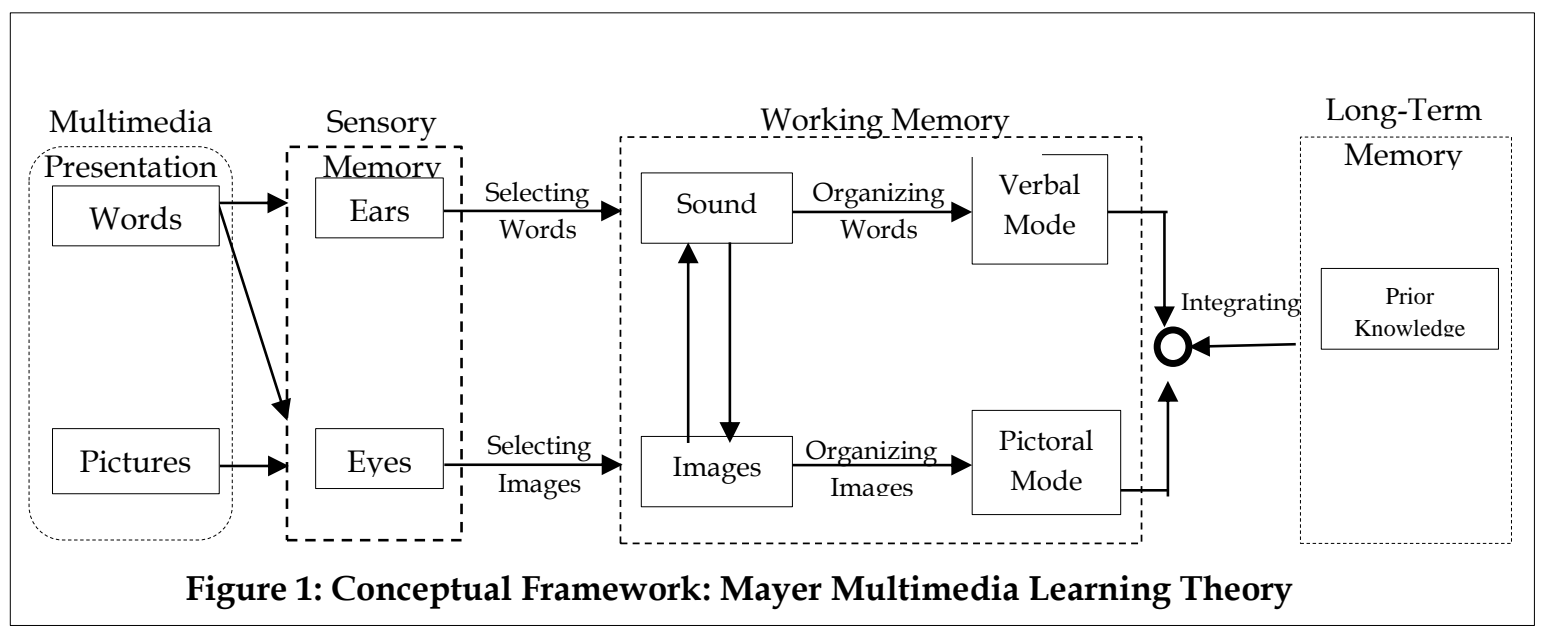

\subsection{Learning with MOOCs}

Learners worldwide have benefitted from MOOCs (Sidek et al., 2019; Gabaree et al., 2020;). During the Covid-19 pandemic, learners were able to evaluate their courses at home. Consequently, MOOCs were elevated as a new teaching method that overcame the limits of traditional teaching platforms, by allowing students to learn from any place and at any time (Wang, 2021). Learners invariably benefit from observing videos or by reading lecture notes online. This is a type of remote learning that enables students to learn outside the physical classroom. As a result, 
MOOCs are created under the open-concept or open-education umbrella (Quiliano Terreros et al., 2009). This platform has demonstrated that it supports lifelong learning, in acquiring key knowledge and skills and the much-needed life-skill interactions with peers and live-project exposure (Sonwalkar \& Maheshkar, 2015).

Researchers have identified the key approaches to incorporate MOOCs into classroom lesson plans and schemes of work, including explicitly defining the content, selecting material and subjects, specifying the MOOC and its range, and ensuring that the scope of the MOOC is easily accessible to learners. Additional strategies, such as learning aim, objectives, teaching activities, and assessment, are also central in the preplanning and in delivering effective lessons (de Jong et al., 2019).

MOOCs grades, behavioral (Phan et al., 2016) outcomes and social engagement were found to have favorable connections (Gillani \& Eynon, 2014; Torres \& Beier, 2018). According to these studies, educators and learning designers are encouraged to include learning activities in MOOCs relevant to career demands, in order to increase learners' extrinsic motivations (Deng et al., 2020). In this report, the researchers also said that learners' engagement might be further stimulated by cognitively engaging the course and by inserting suitable formative assessment into such tasks. The length of MOOCs should likewise be kept to a minimum, in order to maintain pupils' attention. As with all online programmes, the most challenging aspect of MOOCs is student dropout. Students would invariably leave the course if they become demotivated; and if they fail to manage their time effectively. To compensate for this, MOOCs should last between 1 and 16 weeks. However, the MOOCs' inventor strongly suggests that programmes should last no longer than seven weeks.

Various studies reported that financial literacy could be effectively enhanced through online learning (Kalmi, 2017). All previous studies suggested that using digital tools, such as videos or games, could effectively enhance students' financial literacy. Additional studies also revealed that videos, or other digital tools, could effectively improve financial knowledge, whether in college or in high school (Zhu, 2019; Popovich et al., 2020). MOOCs with multimedia, in line with the conceptual framework of this research, were selected as being the most suitable platform for promoting financial literacy in this paper.

\section{Methodology}

\subsection{Research Design}

A mixed-methods research design was used in this study. A survey design was used in quantitative research; whereas, in qualitative research, an interview was used. The researchers selected the mixed-method research method; since they felt a need to comprehend this topic throughout various research phases, and as part of the validation process (Creswell \& Clark, 2017). 


\subsection{Population and Sampling technique}

The target population of this study is 100 pre-service Economics teachers in Peninsular Malaysia. Consequently, a total of 100 pre-service teachers, majoring or minoring in Economics, were selected as quantitative samples. Each sample selected was between the ages of 20 and 21. A random sampling procedure was used to select the respondents. The target respondents were represented with a code number, and the selection was based on the randomly generated number by using Microsoft Excel.

A method known as purposive sampling was employed for the interviewed respondents. Five teacher candidates were also chosen for a follow-up interview. The goal of the follow-up interview was to ensure the triangulation of the data. The participants were selected on the basis of their daily expenditure. Although gender was not considered in this study, two boys and three girls were selected to participate in the interview.

\subsection{Instrument}

The principal researcher created a 50-item closed-ended questionnaire, with five Likert scales, which were then checked by professionals: Financial literacy, collaborative skills, accountability, problem-solving, and decision-making were the five main components of this set of questionnaires. There were ten questions in each section. The questionnaire's reliability was tested in a pilot study with 53 pre-service teachers; while a group of information-technology experts tested the MOOC platform's functionality. All the items in this survey were found to be reliable and acceptable, with a value of 0.70 or above (Sekaran \& Bougie, 2010); because the questionnaire's Cronbach Alpha was 0.832. The pre-service teachers were given an online assessment with 20 questions regarding financial literacy, in order to test their content understanding.

\subsection{The Research Procedure}

All of the pre-service teachers attended a six-week MOOC course. During handson activities, the candidates were divided into 25 groups of four each. This learning activity should improve their collaborative learning via peer dialogue and debate.

The following was the schedule for the six-week course:

All pre-service teachers were required to attend a two-week course on understanding fundamental financial literacy for the first two weeks. The preservice teachers progressed to learning how to incorporate financial literacy into their lessons. Financial planning was also taught to the pre-service teachers. On week three, the pre-service teachers were asked to choose a secondary school economics sub-topic and to construct teaching activities relevant to financial literacy. From weeks three to week six, the researchers peer-shared videos that they had produced.

The pre-service teachers were responsible for designing teaching aids, based on their lesson plan in week four. Pre-service teachers could construct a game on conserving money and knowledge about trust and bonding for money and banking. They evaluated their peers' work from different groups and provided 
constructive feedback and remarks in week five. During the final unit of week six, the pre-service teachers were required to prepare a short case relating to their daily life, together with a financial literacy component. During this week, preservice teachers were required to complete an online quiz and a questionnaire regarding financial literacy. Finally, five pre-service teachers, from various groups, were selected to participate in the interview in week seven.

The five pre-service teachers were all third-year students at a public university. Three females and two males were selected as interviewees. They all participated in the MOOC as self-directed learners, devoting at least one hour every week to the course. Although they were from various groups, they all completed and submitted the tasks on time.

\subsection{The Data-Collection Method}

After watching all of the video clips, the questionnaires were handed out in person, and the data were collected anonymously by using a code-number system. This study was also conducted prior to the global pandemic; and it was modelled on a real-life classroom scenario.

Five pre-service teachers were chosen to attend the interview session separately, and each session lasted about 30 minutes. With the permission of the pre-service teachers, the interviews were recorded. The following were the open-ended interview questions:

- How do you incorporate financial literacy into teaching?

- Do you feel that your collaborative skills have improved after attending MOOC?

- Could you understand the importance of accountability in financial literacy?

- Could you tell me about the problem-solving skill that you learnt, after attending the course?

- Do you agree that decision-making is an essential skill in financial literacy? And if so, why?

\subsection{The Data Analysis}

The quantitative data were analyzed with descriptive and inferential statistics. The five main components of the questionnaire were used to compare the mean score; and a t-test was used to determine the significant difference after implementing MOOC among the pre-service teachers. An unstandardized coefficient model was developed to calculate the coefficient. The Pearson correlation was also employed, in order to check the relationship among the variables. SPSS version 23 was used to compute the data.

The qualitative data were then analyzed via content analysis. Content analysis techniques were used to interpret the transcripts of each subject, both explicitly and implicitly throughout the analytical process (Krippendorff, 2019). It commenced with the process of making transcriptions for five interviews, after the completion of three interview sessions. According to Miles and Huberman (2019), the data that were collected from the interviews should be systematically compiled after transcriptions had been made. The interview recording was 
listened to several times, in order to ensure the comprehension thereof; and then the data were stored electronically.

\section{The Results}

5.1 To examine the effectiveness of MOOC for promoting financial literacy among pre-service teachers

The survey results were examined and summarized in Table 1. According to the questionnaire summary, the subscales of the surveys were financial literacy, collaborative skills, accountability, problem-solving, and decision-making. The highest average mean score for ten categories was problem-solving ( $\mathrm{M}=3.80$, $\mathrm{SD}=.776)$, followed by financial knowledge $(\mathrm{M}=3.75, \mathrm{SD}=0.772)$. Accountability received the lowest mean score $(\mathrm{M}=3.41, \mathrm{SD}=0.934)$.

Table 1: Summary of the Questionnaire on MOOC

\begin{tabular}{|l|c|c|c|}
\hline Sub-scale & Item & Average Mean Score & S.D \\
\hline Financial Knowledge & 10 & 3.75 & 0.772 \\
\hline Collaborative Skills & 10 & 3.36 & 1.033 \\
\hline Accountability & 10 & 3.41 & 0.934 \\
\hline Problem Solving & 10 & 3.80 & 0.776 \\
\hline Decision-Making & 10 & 3.52 & 0.846 \\
\hline
\end{tabular}

The results in Table 2 revealed that both the standardized and the unstandardized beta coefficients were significant. The value of the unstandardized coefficients was $69.238(\mathrm{SD}=6.837)$, and the $t$ value was $10.097(\mathrm{p}<0.05)$. On the other hand, the standardized coefficients showed a value of 0.073 with a $t$ value of $0.721(p<0.05)$. According to the unstandardized coefficient, increases in the financial literacy of one unit should boost students' use of MOOC. The variance in financial literacy is examined through the semi-partial correlation $=20 \%\left(0.452^{2}\right)$. The Tolerance value is 0.751 , which higher than $0.63\left(1-R^{2}\right)$, which showed that there could not be any multi-collinearity.

Table 2: Coefficients

\begin{tabular}{|c|c|c|c|c|c|c|c|c|c|c|}
\hline \multirow[t]{2}{*}{ Model } & \multicolumn{2}{|c|}{$\begin{array}{c}\text { Unstandardized } \\
\text { Coefficients }\end{array}$} & \multirow{2}{*}{$\begin{array}{c}\begin{array}{c}\text { Standardized } \\
\text { Coefficients }\end{array} \\
\text { Beta }\end{array}$} & \multirow[t]{2}{*}{$t$} & \multirow[t]{2}{*}{ Sig. } & \multicolumn{3}{|c|}{ Correlations } & \multicolumn{2}{|c|}{$\begin{array}{c}\text { Collinearity } \\
\text { Statistic }\end{array}$} \\
\hline & B & $\begin{array}{l}\text { Std. } \\
\text { error }\end{array}$ & & & & $\begin{array}{l}\text { Zero- } \\
\text { order }\end{array}$ & Partial & Part & Tolerance & VIF \\
\hline Constant & 69.238 & 6.857 & & 10.097 & 0.00 & & & & & \\
\hline MOOC & 0.067 & 0.093 & 0.073 & 0.72 & 0.00 & 0.478 & 0.45 & 0.37 & 0.751 & 1.315 \\
\hline
\end{tabular}

* significant at $p<.05$

DV: Financial literacy

Adjusted $\mathrm{R}^{2}=.37$

5.2 To investigate the correlation among the variables of financial literacy, collaborative skills, accountability, problem-solving and decision-making The results of the Pearson correlation are shown in Table 3. There were ten different correlations, which means that ten coefficients were statistically significant. Financial literacy was significantly correlated with collaborative skills, $\mathrm{r}=0.118(\mathrm{p}<0.05)$. In addition, financial literacy also correlated with accountability significant, $r=0.216(p<0.05)$. In addition, financial literacy 
correlated with decision-making, $r=0.227(\mathrm{p}<0.001)$ and problem-solving $\mathrm{r}=$ $0.240(\mathrm{p}>0.001)$.

On the other hand, collaborative skill was significantly correlated with all the variables. For example, collaborative skills correlated with accountability, with $r$ $=0.288(\mathrm{p}<0.001)$, problem-solving with $\mathrm{r}=0.202(\mathrm{p}<0.001)$, decision-making with $r=0.346(p<.001)$. Accountability was correlated with all the variables, such as problem-solving with $\mathrm{r}=0.369(\mathrm{p}<0.001)$, accountability with $\mathrm{r}=0.327$ ( $\mathrm{p}$ $<0.001)$ and decision-making $\mathrm{r}=0.494,(\mathrm{p}<0.001)$.

Table 3. Pearson Correlations among the variables

\begin{tabular}{|c|c|c|c|c|c|c|}
\hline \multicolumn{7}{|c|}{ Correlations } \\
\hline & & $\begin{array}{c}\text { Financial } \\
\text { literacy }\end{array}$ & $\begin{array}{c}\text { Collaborative } \\
\text { skills }\end{array}$ & Accountability & $\begin{array}{l}\text { Problem } \\
\text { Solving }\end{array}$ & $\begin{array}{l}\text { Decision } \\
\text { Making }\end{array}$ \\
\hline \multirow{3}{*}{$\begin{array}{l}\text { Financial } \\
\text { literacy }\end{array}$} & $\begin{array}{l}\text { Pearson } \\
\text { Correlation }\end{array}$ & 1 & $0.118^{\star}$ & $0.216^{* *}$ & $-0.240^{* *}$ & $0.227^{* *}$ \\
\hline & Sig. (2-tailed) & & 0.018 & 0.000 & 0.427 & 0.000 \\
\hline & $\mathrm{N}$ & 100 & 100 & 100 & 100 & 100 \\
\hline \multirow{3}{*}{$\begin{array}{l}\text { Collaborative } \\
\text { skills }\end{array}$} & $\begin{array}{l}\text { Pearson } \\
\text { Correlation }\end{array}$ & $0.118^{*}$ & 1 & $0.288^{* *}$ & $0.202^{* *}$ & $0.346^{* *}$ \\
\hline & Sig. (2-tailed) & 0.018 & & 0.000 & 0.000 & 0.000 \\
\hline & $\mathrm{N}$ & 100 & 100 & 100 & 100 & 100 \\
\hline \multirow{3}{*}{ Accountability } & $\begin{array}{l}\text { Pearson } \\
\text { Correlation }\end{array}$ & $0.216^{*}$ & $0.288^{* *}$ & 1 & $0.369^{* *}$ & $0.494^{* *}$ \\
\hline & Sig. (2-tailed) & 0.000 & 0.000 & & 0.000 & 0.000 \\
\hline & $\mathrm{N}$ & 100 & 100 & 100 & 100 & 100 \\
\hline \multirow{3}{*}{$\begin{array}{l}\text { Problem } \\
\text { Solving }\end{array}$} & $\begin{array}{l}\text { Pearson } \\
\text { Correlation }\end{array}$ & -0.040 & $0.202^{* *}$ & $0.369^{* k}$ & 1 & $0.327^{* *}$ \\
\hline & Sig. (2-tailed) & $-0.240^{* *}$ & 0.000 & 0.000 & & 0.000 \\
\hline & $\mathrm{N}$ & 100 & 100 & 100 & 100 & 100 \\
\hline \multirow{3}{*}{$\begin{array}{l}\text { Decision } \\
\text { Making }\end{array}$} & $\begin{array}{l}\text { Pearson } \\
\text { Correlation }\end{array}$ & $.227^{* *}$ & $.346^{* *}$ & $.494^{* *}$ & $.327^{* *}$ & 1 \\
\hline & Sig. (2-tailed) & 0.000 & 0.000 & 0.000 & 0.000 & \\
\hline & $\mathrm{N}$ & 100 & 100 & 100 & 100 & 100 \\
\hline
\end{tabular}

*. Correlation is significant at the 0.05 level (2-tailed).

**. Correlation is significant at the 0.01 level (2-tailed).

\subsection{Pre-service teachers' views after attending MOOC}

A total of five pre-service teachers attended the interview. To protect their identities, they used pseudonyms. Their opinions on financial literacy, collaboration, accountability, problem-solving, and decision-making were polled. All of these enquiries were related to the questionnaires.

\subsubsection{Financial literacy}

Eighty per cent of the participants said that they strongly believed their financialliteracy understanding had improved, and that they could incorporate the lessons' skills. They were well-versed in how to instil financial literacy in students; and they had created appropriate teaching aids. When asked how to incorporate financial literacy into teaching, these individuals said: 
"... select a suitable topic, like demand and supply, by using a video clip." (Male 1)

"... I would start with a story; and I would then give the class a problem-solving task." (Female 2)

"... set an online platform, with an element of financial literacy, and then allow students to have self-directed learning." (Female 3)

This cohort of pre-service teachers had mastered many skills through MOOC; and they expressed their enthusiasm for MOOC learning. They had also gained financial knowledge through the platform (Deng \& Benckendorf, 2021). Preservice teachers created teaching aids, shared their ideas with their colleagues, and commented on their peers' work.

\subsubsection{Collaborative Skills}

During group discussions, one can always improve collaborative skills. MOOC provides a venue for pre-service teachers to learn and share. To finish the assignment, they had to work together. Each of the participants has a certain role to play, based on the work at hand. Each week, the group leaders were rotated among the pre-service teachers. The job had to be distributed equitably among the pre-service teachers by the leaders (Duret et al., 2019). For example, during a session of creating teaching aids, one person would prepare the video's storyline and script, two members would prepare the video, and a third member would get the task of editing the video. The successful completion relied heavily on team collaboration. When asked whether they had developed collaborative skills after attending the MOOC, they expressed their delight; and they noted that they each had contributed something:

"... I did my work, according to our leader's instruction, and I completed my task within the allocated timeframe. We learnt how to help each other every week, and we learnt from each other too. Everybody acquired different strengths." (Female 1)

Aside from collaborative abilities, pre-service teachers were accountable for their work. As a result, responsibility is a necessary skill in the teaching profession. It also has a significant impact on financial literacy.

\subsubsection{Accountability}

Accountability is an important element in financial literacy (Rakow, 2019). All the pre-service teachers agreed that they understood the importance of accountability in financial literacy. They also practised it when they had completed the task given during MOOC learning. They learnt the meaning of accountability in financial literacy through the weekly videos provided. Some of them tried to incorporate the value of accountability, when designing the teaching aids.

"... I put the value of accountability into my teaching aid. I made a music video related to financial literacy for the chapter on money and banking; then I incorporatedl this value." (Male 2)

All of the pre-service teachers agreed that accountability in financial literacy is an important element. They practised it as well; since they completed the MOOC learning activity. Through the weekly videos, they learned about the need for 
accountability in financial literacy. When creating instructional tools, some of the pre-service teachers attempted to incorporate the concept of accountability.

\subsubsection{Problem-solving}

One of the pre-service teachers provided a proactive problem-solving example. During the MOOC, she used a case study, as a teaching tool. She asked the students to assume the scenario that they were alone, without savings or investments. The scenario included the visualization of their payday, in which a snatch robber took their handbag/wallet. Meanwhile, they had to imagine that they had received a call from their hometown, informing them that their mother was gravely ill, and required financial assistance. The question that was posted among pre-service teachers was: 'What are your options for resolving this issue?'

"... I try to figure out the suitable situation for high-school students who had just started to learn financial literacy. I made the question a little trickier; and I let them think that I had set a few learning activities for me to incorporate into the lessons during my teaching practicum." (Female 1)

Other pre-service teachers provided a good example of problem-solving, too. The activities that the pre-service teachers devised could be used during their practicum. By doing so, the pre-service teachers gained further insights and content knowledge through practical exposure and case-study analysis (Wright et al., 2017).

\subsubsection{Decision-Making}

The comments of the pre-service teachers suggested that one of the components they had to acquire in financial literacy and collaborative work in MOOC was decision-making. They all agreed that financial literacy requires good decisionmaking skills. Decision-making is an essential skill in financial literacy (Sonwalker \& Maheshkar, 2015). They also expressed their opinions on the necessity of deciding to complete the work. For example, they chose their lesson plan or learning activities and the teaching aids they created were based on mutual agreement and decision-making. In order to meet the requirements of incorporating financial literacy into lessons, they had to decide on a topic, what materials to use as teaching aids, and what learning activities to implement.

"... I kept on discussing matters with my members, when I was the leader of the group. I cannot decide on my own; I have to consider all their abilities and strengths. Some of them are good in making videos, but others are good in animation or singing." (Male 2)

\section{Discussion}

The effectiveness of MOOC in increasing financial literacy was investigated in this study. In descriptive statistics, the quantitative results demonstrated positive results for financial literacy. they showed a medium-high average, ranging from 3.41 to 3.80, because the MOOC was implemented in a short duration. On a shortterm basis, the influence of learning, particularly value, could not be seen. However, in terms of regression, the results were significant ( $t$ value 10.097) $(\mathrm{p}<0.05)$ for an unstandardized model and a $\mathrm{t}$ value of $0.721(\mathrm{p}<.05)$ for a standardized model. 
The Pearson coefficient revealed a correlation for financial literacy. The results showed that financial literacy was statistically related to collaborative skills, accountability, problem-solving, and decision-making. The results are consistent with the literature review of Bakar and Bakar (2020) and Compen et al. (2020). It was discovered that financial literacy might well be improved through MOOCs and digital learning. MOOC is a learning platform that allows learners to learn from professionals worldwide, and thereby go enhance their abilities (Clark et al., 2017). In Mayer's Learning Theory, students could learn new knowledge better by combining words and pictures, for example, videos in MOOC.

The qualitative results revealed that MOOC could improve collaboration skills, problem-solving skills, accountability, and decision-making skills. Previous research had found that online or blended learning improves collaborative skills (Compen et al., 2020). Studies also reported that online learning is able to enhance problem-solving (Yeen-Ju et al., 2015). On the other hand, online learning also promotes accountability (Pulukuri \& Abrams, 2020), as well as the decisionmaking ability of learners (Galvis, 2018; Compen et al., 2020).

During the course, pre-service teachers were required to create videos, in order to obtain practical experience and to learn how to include financial literacy into the curriculum. The videos were created by pre-service teachers; and they included technology, animation, and problem-solving activities. These videos serve as a wake-up call for students interested in learning about financial literacy. Preservice teachers also chose a problem that was relevant to their students' daily lives. These qualitative results supported the conclusions of Kuntze et al. (2019) that videos are an effective online method for delivering financial literacy knowledge outside the classroom, and for reinforcing it.

Additionally, videos can be used as post-class reinforcement tools for increasing students' learning interest, allowing them to study more interactively (Pulukuri \& Abram, 2020). The MOOC course also provided a forum for pre-service teachers to socialize, share ideas, and engage in practical exercises. When pre-service teachers were involved in the learning process, they developed a positive outlook (Gurvitch \& Lund, 2014). This mindset should benefit them in both their behaviour and in their future teaching. This finding is consistent with the research of Amagir et al. (2019).

In addition, previous research mentioned that ICT significantly benefits learners (Gaboy et al., 2020), especially in financial literacy (Lusardi et al., 2015), which is similar to the results found in this study. Both studies also mentioned visual tools; videos that can enhance financial literacy more interactively. In addition, with the assistance of fingertip technology, students can learn anywhere and at any time (Shah et al., 2019). Moreover, universities can engage with schools and invite students to engage in their learning platforms with the assistance of mobile phone technology (Che Kob et al., 2020).

Furthermore, previous research has found that ICT benefits learners (Gaboy et al., 2020), particularly in financial literacy (Amagir et al., 2019), which is consistent 
with the results of this study. Both types of research addressed visual aids, as well as videos that can help people to learn more about money. Furthermore, students can learn anywhere and at any time, by using finger-tip technology (Shah et al., 2019). With the advancement of mobile phone technology, universities may engage with schools and ask students to participate in their learning platforms (Che Kob et al., 2020).

The use of mobile phone technology might be a solution for teachers who claim that they do not have enough time to incorporate financial literacy into the curriculum because it explores a learning platform that allows self-directed learning beyond the classroom.

\section{Limitations}

The following were some noticeable limitations in this study:

Firstly, the samples of this study were restricted to pre-service teachers from major or minor economics only. Pre-service teachers from other courses were not included in this study. Therefore, studies should be conducted among different courses before any generalizations of financial literacy can be made. Secondly, inservice teachers were excluded from this study. This scenario has limited the results regarding the generalization of the efficacy of financial literacy for MOOCs.

\section{Future Research}

Pre-service teachers should produce and share projects on various topics about financial literacy across the curricula in various subjects when using MOOCs. A possible issue to investigate the incorporation of financial literacy in different subjects, such as Accounting and Business Management will probably become the future research direction. Financial planning is another future research direction; since this issue is only a small segment of the current research. In future research, the researchers can consider doing in-depth financial literacy training for preservice and in-service teachers in terms of investment and possible retirement plans.

\section{Recommendations}

From the results, we would like to make some recommendations that might be useful to educators and researchers. These engagements were divided into two categories: course design and participation engagement.

- Course design

Course design is an essential aspect of attracting and retaining participants. A robust course considering the students to get the basic knowledge and make the students learn with pleasure would result in a better success percentage. The course content could consider elements related to students' prior knowledge, whereas learning activities can design familiar activities. When educators design any courses related to financial literacy, learning activities such as videos, quizzes, and games could be a good choice for initial learning.

- Participants' engagement in participation 
To make the course successful, one should try to include as many activities as possible that need to be implemented in the participation. Hand-on activities are one way to let students engage in the learning activities; for example, students can work in a group to produce a video related to financial literacy. Teachers' lively teaching approach, or group activities coulc also attract students' participation. Students could gain basic financial knowledge through a platform that attracts their interest. Another option is to send a notification or a push button to participants to inform them of the task's deadline.

\section{Conclusion}

In this study, pre-service teachers were exposed to various events that put them in perspective and inspired them to be innovative in teaching their students' financial-planning skills and principles. Alternatively, financial planning is a vital part of children's discipline, which ought to be instilled. This study researched the various approaches to teach pre-service teachers how to instil supportive ideals in their students to become responsible for themselves. The positive results of this study are encouraging, given the literature review related to financial literacy related to collaborative skills, accountability, problem-solving and decisionmaking. The mentioned skills are transferable skills that are needed to enhance financial literacy. From the results, the study suggests that MOOC coulc promote financial literacy among pre-service teachers effectively. Therefore, educators and researchers could provide more online learning opportunities that combine financial literacy in Economics, Accounting, Mathematics, or even in languages.

Personal finance is rarely discussed at school or at home; educators should seize the opportunity to teach the future generation the importance thereof. We are assisting parents in protecting the future of their children by shaping the next generation.

\section{Acknowledgement}

This research has been carried out under the Fundamental Research Grants Scheme (FRGS/1/2019/SS08/UPSI/02/3) provided by the Ministry of Education of Malaysia. The authors would like to extend their gratitude to Universiti Pendidikan Sultan Idris (UPSI), that helped to manage the grant. The authors also would like to thank Vasiliki Kondou Watson for editing in this paper.

\section{References}

Angel, S. (2018). Smart tools? A randomized controlled trial on the impact of three different media tools on personal finance. Journal of Behavioral and Experimental Economics, 74, 104-111. https://doi.org/10.1016/j.socec.2018.04.002

Amagir, A., Groot, W., Brink, H. M. V. D., \& Wilschut, A. (2019). SaveWise: the design of a financial education program in the Netherlands. Citizenship Social \& Economics Education, 18(2), 100-120. https://doi.org/10.1177/2047173419870053

Bakar, M. Z. A., \& Bakar, S. A. (2020). Prudent financial management practices among Malaysian Youth: The moderating roles of financial education. The Journal of Asian Finance, Economics and Business, 7(6), 525-535. http://doi.org/10.13106/jafeb.2020.vol7.no6.525 
Caixeta, C. C., Nascimento, J. A., \& Abrem, A. M. (2016). The influence of social media on consumer perception on brand. Espacious, 37(27), 17-26. http://dx.doi.org/10.5195/emaj.2019.173

Che Kob, C. G., Kannapiran, S., \& Shah, A. (2020). The usage of mobile learning: comparative studies among technical and vocational education students in selected universities. International Journal of Interactive Mobile Technologies, 14(5), 203-209. https://doi.org/10.3991/ijim.v14i05.13355

Clark, K. R., Vealé, B. L, Watts, L. K. (2017). A Review of the Use of Massive Open Online Courses (MOOCs) in Medical Imaging Education. The Internet Journal of Allied Health Sciences and Practice, 23, 15(2), 1-6.

https://nsuworks.nova.edu/cgi/viewcontent.cgi?article=1659\&context=ijahsp

Compen, B., Witte, K. D., \& Schelfhout, W. (2020). The impact of teacher engagement in an interactive webinar series on the effectiveness of financial literacy education. British Journal of Educational Technology, 1-15. http:// doi.org. 10.1111/bjet.13013

Cordero, J. M., \& Pedraja, F. (2019). The effect of financial education training on the financial literacy of Spanish students in PISA. Applied Economics, 51(16), 1679-1693. http:// doi.org.10.1080/00036846.2018.1528336

Creswell, J. W., \& Clark, V. L. P. (2017). Designing and conducting mixed-methods research (3rd ed.). California: Sage Publication.

de Jong, P. G. M., Pickering, J. D., Hendriks, R. A., Swineerton, B. J., Goshtasbpour, F., \& Reinders, M. E. J. (2019). Twelve tips for integrating massive open online course content into classroom teaching. Medical Teacher, 42(4), 393-397. https://doi.org/10.1080/0142159X.2019.1571569

Deng, R., Benckendorff, P., \& Gannaway, D. (2020). Linking learner factors, teaching content and engagement patterns with MOOC learning outcome. Journal of Computer Assisted Learning, 1-18. https://doi.org/10.1111/jcal.12437

Deng, R., \& Benckendorff, P. (2021). What are the key themes associated with the positive learning experience in MOOCs? An empirical investigation of learners' ratings and reviews. International Journal of Education Technology in Higher Education, 18 (9), 1-28. https://doi.org/10.1186/s41239-021-00244-3

Duret, D., Christley, R., Denny, P., \& Senior, A. (2019). Collaborative learning with peerwise. Research in Learning Technology, 26, 1-14. http:/ / doi:0.25304/rlt.v26.1979

Financial-Education Network. (2019). Empowering financial freedom. https://www.fenetwork.my/about/

Gabaree, L., Rodeghiero, C., Presicce, C., Rusk, N., \& Jain, R. (2020). Designing creative and connected online learning experiences. Information and Learning Sciences, 121 (7/8), 655-663. https://doi.org/10.1111/jcal.12437

Gaboy, R. G., Mabalay, M. C., Mananghaya, M. E., Mercado, M. G. M., \& Romblon, B. M. (2020). Coping with the new norm: ICT-Pedagogy integration awareness and competency of TEI faculty. Journal of Research, Policy \& Practice of Teachers $\mathcal{E}$ Teacher Education, 10(2), 49-62. http:// doi.org.10.37134/jrpptte.vol10.2.4.2020

Galvis, A. H. (2018). Supporting decision-making processes on blended learning in higher education: literature and good practices review. International Journal of Educational Technology in Higher Education, 15(25), 2-38. http:// 10.37134/jrpptte.vol10.2.4.2020

Gillani, N., \& Eynon, R. (2014). Communication patterns in massively open online courses. The Internet and Higher Education, 23, 18-26. http:/ /dx.doi.org/10.1016/j.iheduc.2014.05.004

Gurvitch R., \& Lund J. (2014). Animated video clips: Learning in the current generation. Journal of Physical Education, Recreation and Dance, 85(5), 8-17. https://doi.org/10.1080/07303084.2014.897566 
Haron, H., Yusof, A. R. M., Samad, H., Ismail, N., Juanita, A., \& Yusof, H. (2019). The platform of MOOC (Massive Open Online Course) on open learning: Issues and challenges. International Journal of Modern Education, 1(3), 01-09.

http://doi.org/10.35631/ijmoe.13001

Hassan, H., Mailok, R., \& Johan, R. (2015). UPSI students' perceptions on the use of ICT in learning: comparison between knowledge testing and task-based testing on ICT competency. Journal of ICT in Education, 2, 5577. https://ejournal.upsi.edu.my/index.php/JICTIE/article/view/2600

Haneger, R., \& Cude, B. J. (2019). Financial literacy of high school graduates: Long and short-term financial behaviour by age group. Journal of Family and Economic Issues, 40, 564-575. http://10.1891/1052-3073.27.1.3

Kalmi, P. (2017). The effects of financial education: Evidence from Finish lower secondary schools. Economic notes, 9999 (9999), 1-34. http:/ / dx.doi.org/10.1111/ecno.12114

Krippendorff, K. (2019). Content analysis: An Introduction to its methodology. Sage publication. https://us.sagepub.com/en-us/nam/content-analysis/book 258450

Khan, H. U. R., Lim, C. K., Tan, K. L. \& Khan, M. R. (2019). Location-based social media content: A conceptual paper on travellers' purchase decisions. Management Research Journal, 8, 30-40. https://doi.org/10.37134/mrj.vol8.3.2019

Khoo, Y. Y., \& Fitzgerald, R. (2017). Pocket cartoons: Learning financial literacy with mobile cartoons in Malaysia. International Journal of Mobile and Blended Learning, 9(4), 49-64. https://doi.org/10.37134/mrj.vol8.3.2019

Kumar, J. A., \& Al-Samarraie, H. (2018). MOOC in the Malaysian higher education institutions: The instructors' perspectives. The Reference Librarian, 1-16. https:// doi.org/10.1080/02763877.2018.1458688

Kuntze, R., Wu, C., Ross, W., \& Whuang, Y. (2019). Improving financial literacy in college of business students: Modernizing delivery tools. Emerald Insight, 37(4), 976-990. https:// doi.org/10.1108/IJBM-03-2018-0080

Lusardi, A., Samek, A., Kapteyn, A., Glinert, L., Hung, A., Heinberg, A. (2015). Visual tools and narratives: New ways to improve financial literacy. Journal of Pension Economics and Finance, 16(3), 297-323. https://doi.org/10.1017/S1474747215000323

Malaysian Communications and Multimedia Commission. (2015). Hand phone user survey 2014. Kuala Lumpur. https://www.mcmc.gov.my/ms/home.

Mayer, R. E., Lee, H., \& Peebles, A. (2014). Multimedia Learning in a Second Language: A Cognitive Load Perspective. Applied Cognitive Psychology, 28(5), 653 660. https://doi.org/10.1002/acp.3050

Miles, M. B., \& Huberman, A. M (2019). Qualitative Data Analysis $4^{\text {th }}$ Edition. USA: Sage Publications.

Mohd Aziz, N. I., \& Kassim, S. (2020). Does financial literacy really matter for Malaysians? A review. Advanced International Journal of Banking, Accounting and Finance, 2(2),1320. http://dx.doi.org/10.35631/AIJBAF.22002

Murugiah, L. (2016). The level of understanding and strategies to enhance financial literacy among Malaysians. International Journal of Economics and Financial, 6(S3), 130-139. https://www.econjournals.com/index.php/ijefi/article/view/2621

Nurul Afiqah. (2016). The relationship between the level of financial literacy and investment by decision-making millennials in Malaysia. Taylor's Business Review, 6, 39-47. http://dx.doi.org/10.18488/journal.137.2020.42.110.126

Phan, T., McNeil, S. G., \& Robin, B. R. (2016). Students' patterns of engagement and course performance in a massive open online course. Computers $\mathcal{E}$ Education, 95, 36-44. https://doi.org/10.1016/j.compedu.2015.11.015 
Popovich, J. J., Loibl, C., Zirkle, C., \& Whittington, M. S. (2020). Community-college students' response to a financial literacy intervention: An exploratory study. International Review of Economics Education, 34 (2020), 1-15. http://dx.doi.org/10.1016/j.iree.2020.100182

Prajapati, R., Sharma, F. B., \& Sharma, F. D. (2017). Significance of life skills education. Contemporary Issues in Education Research, 10(1), 1-6. https://eric.ed.gov/?id=EJ1126842

Pulukuri, S., \& Abrams, B. (2020). Incorporating an online interactive video platform to optimize active learning and improve student accountability through educational videos. Journal of Chemical Education, 97, 4505-4514. https://pubs.acs.org/doi/10.1021/acs.jchemed.0c00855

Rakow, K. C. (2019). Incorporating financial literacy into the accounting curriculum. Accounting Education, 28(4), 384-400. https://doi.org/10.1080/09639284.2019.1578247

Sawatzki, C., \& Sullivan, P. (2017). Teachers' Perceptions of financial literacy and the implications for professional learning. Australian Journal of Teacher Education, 42(5), 51-65. http://dx.doi.org/10.14221/ajte.2017v42n5.4

Sekaran, U., \& Bougie, R. (2010). Research methods for business: A skill building approach

(5th ed). New York, NY: John Wiley \& Sons Ltd. Sidek, S. F., Mohamad Yatim, M. H., Ariffin, S. A., \& Nurzid, A. (2019). The acceptance factors and effectiveness of MOOC in the blended learning of computer architecture and organization course. Universal Journal of Education Research, 8(3), 909-915. https://doi.org/10.30534/ijatcse/2019/3281.32019

Shah, A., Suhailiezana, Che Kob, C. G., \& Khairudin, M. (2019). Effectiveness of M Learning applications for design and technology subject. International Journal of Interactive Mobile Technologies, 13(10), 120-133. http://dx.doi.org/10.3991/ijim.v13i10.11324

Torres, W. J., \& Beier, M. E. (2018). Adult development in the wild: The determinants of autonomous learning in a Massive Open Online Course. Learning and Individual Differences, 65, 207-217. https://doi.org/10.1016/j.lindif.2018.06.003

Qaffas, A. A., Kaabi, K., Shadiev, R., \& Essalui, F. (2020). Towards an optimal personalization strategy in MOOC. Smart Learning Environment, 7(14), 1-18. https://doi.org/10.1186/s40561-020-0117-y

OECD. (2013). Education at a glance 2013: OECD indicators. OECD. http://www.oecd.org/education/eag2013\%20(eng)FINAL\%2020\%20June\%2020 13.Pdf

OECD. (2014). Education at a glance. http://www.oecd.org/daf/fin/financialeducation/financial-education-for-youth.htm

Quiliano Terreros, A., Del Carmen, R., Jesús, P., \& Durán, B. (2009). Systematic mapping study 2012-2017: Quality and effectiveness measurement in MOOC. Turkish Online Journal of Distance Education, $20 \quad$ (1), 223247.http://hdl.handle.net/11285/632793

Wang, Z. (2021). Financial management teaching mode based on MOOC under the background of informatization. In: Sugumaran V., Xu Z., Zhou H. (Eds.) Application of Intelligent Systems in Multi-modal Information Analytics. MMIA 2020. Advances in Intelligent Systems and Computing, 1233. Retrieved from https://link.springer.com/book/10.1007/978-3-030-15740-1

Wright, M. C., Bergom, I., \& Bartholomew, T. (2017). Decreased class size, increased active learning? Intended and enacted teaching strategies in smaller classes. Active Learning in Higher Education, 1-17. https:/ / doi.org/10.1177\%2F1469787417735607 
Yeen-Ju, T., H, Neo, M., \& Salvaretnam, B. (2015). Enhancing problem-solving skills in an authentic blended learning environment: a Malaysian context. International Journal of Information and Education Technology, 5 (11), 841-846. http://dx.doi.org/10.7763/IJIET.2015.V5.623

Zhu, A. Y. F. (2018). Financial literacy among Hong Kong's Chinese adolescents: testing the validity of a scale and evaluating two conceptual models. Youth $\mathcal{E}$ Society, 126. https://doi.org/10.1177\%2F0044118X17753813

Zhu, A. Y. F. (2019). School financial education and parental financial socialization: Findings from a sample of Hong Kong adolescents. Children and Youth Service Review, 107, 1-10. http://doi.org/10.1016/j.childyouth.2019.104532 